\title{
Low-Income Countries and an SDR-based International Monetary System
}

\author{
Pietro Alessandrini • Andrea F. Presbitero
}

Published online: 24 December 2011

(C) The Author(s) 2011. This article is published with open access at Springerlink.com

\begin{abstract}
The global financial crisis, the weakening role of the dollar and the increasing international importance of China are calling for a reform of the international monetary system in the direction of greater multilateralism. To this end, we advance a proposal based on a greater role of the Special Drawing Rights (SDRs) and focus on the potential benefits that these could bring to Low-Income Countries (LICs). SDRs would be created exogenously - with a disproportionate allocation to LICs -, but also endogenously, through a substitution account and an overdraft facility. Finally, the paper discusses the superiority of this proposal in the context of the current foreign assistance framework.
\end{abstract}

Keyword International monetary system $\cdot$ Low-income countries, SDR · Key currency $\cdot$ Reserves

JEL classification $\mathrm{O} 11 \cdot \mathrm{O} 19 \cdot \mathrm{F} 55 \cdot \mathrm{F} 35 \cdot \mathrm{F} 33$

The authors gratefully acknowledge Michele Fratianni (the editor), Andrea Fracasso, and two anonymous referees for insightful comments on a previous version of the paper.

P. Alessandrini - A. F. Presbitero $(\bowtie)$

Department of Economics and Social Sciences, Università Politecnica delle Marche, Ancona, Italy

e-mail: a.presbitero@univpm.it

URL: https://sites.google.com/site/presbitero/

P. Alessandrini

e-mail: p.alessandrini@univpm.it

URL: www.univpm.it/pietro.alessandrini/

P. Alessandrini - A. F. Presbitero

Money and Finance Research group (MoFiR), Ancona, Italy

A. F. Presbitero

Centre for Macroeconomic and Finance Research (CeMaFiR),

Milan, Italy 
Ministers asked the IMF to continue to explore options to improve the international monetary system, including through a greater role for SDRs and expansion of the SDR basket to include emerging markets currencies. They called for regular allocations of SDRs to complement the reserves of members. Ministers emphasized that reserves have played an important role in cushioning the impact of the crisis.

G24 Communiquè, April 14, 2011

\section{Introduction}

The policy discussion about the reform of the international monetary system (IMS) mainly focuses on the China - US dispute and the exorbitant privilege enjoyed by the United States as a dominant-currency country; alternatively, the discussion emphasizes the excessive Chinese saving rates as the main sources of rising global imbalances. In other words, macroeconomic imbalances are often confined to a huge US current account surplus financed by China and few other oil-producer countries. Even if the sino-american relationship clearly accounts for the largest share of global imbalances and therefore justifies on its own the growing debate about the reform of the IMS, the current international monetary order imposes costs on several developing countries, which have accelerated the accumulation of reserves for precautionary reasons. Thus, also Low-Income Countries (LICs) could benefit from a multi-polar reform of the IMS and a diversification of reserve assets away from the US dollar. In particular, as the opening quote makes it clear, developing countries seek an increasing role of the Special Drawing Rights (SDRs) and a revamping of the original proposal advanced in the 1970s, which called for a disproportionate allocation of these rights to poor countries so as to provide them with unconditional liquidity and development finance (Grubel 1972; Maynard 1973; Helleiner 1974; Bird and Maynard 1975; Bird 1979). ${ }^{1}$ Those wealthredistributive proposals were abandoned for years, creating a missing opportunity to help poor countries, but have resurfaced first in response to the emerging market crisis of the late 1990s and the financing of the Millennium Development Goals (MDG), and later as an aftermath of the widening of global imbalances in the new millennium. In 2002, George Soros and the United Nations with the Zedillo report advocated the use of SDRs for development assistance purposes, especially because of the high cost of holding reserves faced by developing nations, a point stressed also by Stiglitz (2003). Similarly, Clark and Polak (2004) made a strong argument in favour of the efficiency gains of SDRs as a costless reserve asset. ${ }^{2}$ The current international environment and the awareness of the global extent of poverty in LICs make the SDR aid link very timely to help poor countries meeting their crisis-induced financing gap (Akyuz 2010; Bird 2010). The same aim and a partial stabilization of global imbalances might be achieved taxing SDR allocations to countries with a current account surplus and using the revenues to fulfil developing countries' needs (Stiglitz and Greenwald 2010).

It comes as no surprise that the current discussions resemble the debate on monetary issues in the 1960s and in the 1970s, about which Bird and Maynard $(1975$, p. 611) wrote that "relatively few references to the special interests on LDCs can be found in the academic literature of the period. It was thought self evident that

\footnotetext{
${ }^{1}$ See Bordo and James (2012, in this issue) for an historical discussion of the SDR creation.

${ }^{2}$ An extensive review of these and other proposals is in Aryeetey (2004).
} 
the economic development and the trading prospects of the LDCs depended on the efficient functioning of the international monetary system [..., which] was thought to be determined by the policies and practices of major industrial countries [...] Also, it was felt that the provision of conditional liquidity and the handling of balance-ofpayments adjustment problems in the case of the LDCs could be safely left to the $I M F$. Hence much of the literature dealing with LDCs and the international monetary system refers to relations, often uneasy, between the former and the IMF'.

The renewed interest in SDRs and the lack of voice by poor countries were reflected in the agreement reached at the G-20 London Summit in April 2009, when a new allocation of SDR 182.7 billion was approved. ${ }^{3}$ As in the past, the allocation was based on country quotas without any regard to a wealth-redistributive principle. As a result, LICs received SDR 7.7 billion and their world share of SDRs at the end of 2009 remained stable at $4.2 \%$.

On the whole, the use of SDRs has been limited. Between September 2009 and July 2011, only 24 of the 186 IMF member countries have deployed more than $50 \%$ of their SDR holdings. Similar to what happened after the first SDR allocation, when developing countries made a disproportionate use of the facility (Helleiner 1974), after the last allocation 37 of the 44 LICs have reduced their SDR holdings, while LICs as a group have reduced theirs by $11 \%{ }^{4}$

An expanded role of the SDRs would generate several benefits, this paper focuses on two of them. The first is related to the provision of development finance and the relaxation of LICs' external constraint; the second arises from stabilizing the IMS through a lower demand of precautionary reserves by LICs.

The strong relationship between IMS fragility and LICs' vulnerabilities makes the issue of IMS stabilization the key point of our analysis. The first objective of a new SDR scheme would be the reform of the IMS; which would also mitigate, as a byproduct, LICs' vulnerabilities. The second objective of a new SDR scheme is the design of an efficient allocation and distributional mechanism. This mechanism should be inspired by two principles. The first is a redistribution of wealth in favour of developing countries, in the spirit of the original aid link proposals. The second is to avoid the standard failure imbedded in traditional aid assistance: LICs could have access to an unconditional overdraft facilities, up to a predetermined threshold, obtained once the new SDR-denominated deposits are exhausted due to exogenous shocks. In this way, it would be possible to design a more efficient aid allocation scheme, without incurring in Washington consensus-like policy conditionality and in the geo-strategic interests underlying foreign aid allocation.

The paper is structured as follows. Section 2 focuses on LICs' economic vulnerability and external financing. Under the current IMS, LICs are accumulating

\footnotetext{
${ }^{3}$ Following the London G-20 meeting, two new SDR allocations were implemented, one for 161.2 and the other for 21.5 billion, bringing the outstanding stock of SDRs to 204 billion.

${ }^{4}$ Central African Republic, Chad, Kenya, Malawi, Mauritania, and Myanmar spent SDRs for more than $90 \%$ of their end-2009 allocation to reach different targets in terms of external and fiscal balance. Malawi, for instance, was forced by the worsening foreign exchange shortage to sell the 2009 special allocation of SDRs to address balance of payments pressures (IMF 2010a). In Mauritania, the deterioration of the fiscal position forced authorities to use the SDR allocation to help close the fiscal financing gap (IMF 2010b). Differently, Central African Republic authorities have decided to use part of the SDR allocation to pay off part of the more expensive domestic debt, improving debt sustainability and possibly freeing resources to be used for additional social spending (IMF 2010c).
} 
costly international reserves and striving for a diversification in the currency composition of their reserve assets. Section 3 keys on the need to reform the IMS, discusses the inadequacy of the original SDR scheme and the repeated failures to improve it. In Section 4 we advance a proposal for a greater role of SDRs in the IMS. First, we suggest that SDRs must be created not only through the traditional exogenous channels, but also through the endogenous channels of the overdraft and substitution account facilities. Furthermore, we analyze how the new SDRs might improve the distribution and uses of the supranational money. Section 5 focuses on the SDRs as a funding mechanism for LICs' balance-of-payments deficits and in the context of the aid effectiveness debate. Finally, concluding remarks are summarized in Section 6.

\section{Economic Vulnerability, International Reserve Hoarding, and Diversification}

\subsection{External Financing and Economic Vulnerability in LICs}

Low-income countries as a group are characterised by a structural trade deficit, which has worsened in the last decade and has reached more than $10 \%$ of GDP. The trade deficit has been traditionally financed through official development assistance and concessional loans. Debt flows, in particular, have been responsible for a buildup of an unsustainable external debt, which has been reduced thanks to bilateral and multilateral debt relief initiatives (Arnone and Presbitero 2010). Starting from the mid-1990s, debt relief, remittance flows and private capital flows have started to partially offset foreign aid as a source of external financing (Fig. 1).

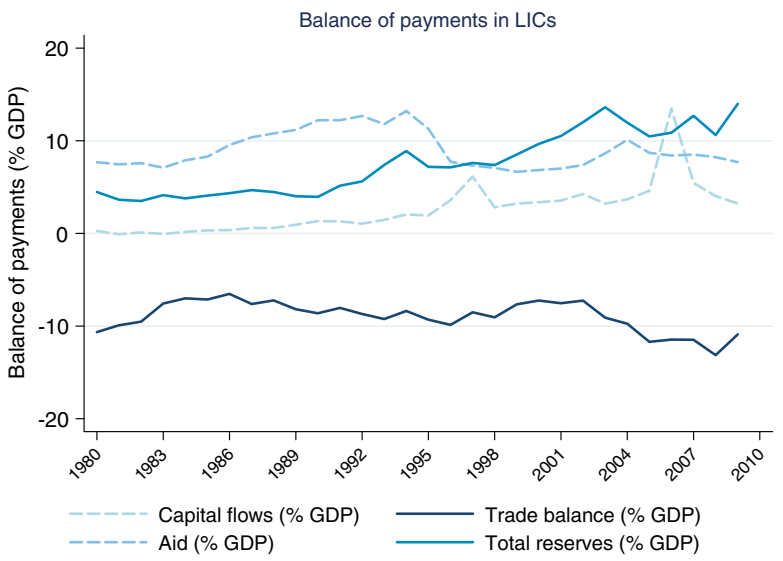

Fig. 1 Balance of payments of low-income countries, 1980-2010. Notes: authors' elaboration on data from the World Development Indicators and Global Development Finance (The World Bank, available at: http://data.worldbank.org/data-catalog; last retrieved: September 2011). Data are GDP-weighed averages across countries. The 37 LICs included are: Bangladesh, Benin, Burkina Faso, Burundi, Cambodia, Central African Republic, Chad, Comoros, Ethiopia, The Gambia, Ghana, Guinea, Guinea-Bissau, Haiti, Kenya, Kyrgyz Republic, Lao PDR, Liberia, Madagascar, Malawi, Mali, Mauritania, Mozambique, Nepal, Niger, Rwanda, Senegal, Sierra Leone, Somalia, Tajikistan, Tanzania, Togo, Uganda, Vietnam, Republic of Yemen, Zambia, Zimbabwe 
In the last twenty years LICs have increased their stock of international reserves. Many LICs have accumulated more reserves than suggested by the standard coverage ratio of imports: in 2009 LICs had median reserves worth 4.7 months of imports, well above the threshold value of three months (IMF 2011a). ${ }^{5}$ These numbers suggest that LICs, to insure against balance-of-payments risks, have employed part of their external financing to accumulate reserves, in preference of alternative uses such as productive investment, external debt reduction, and a lower reliance on costly internal financing.

Poor countries have always been extremely vulnerable to exogenous shocks, such as sharp swings in commodity prices or export volumes, volatile external financing flows, and natural disasters. The recent $3 \mathrm{~F}$ (food, fuel and financial) crisis has once again made this point clear (Deaton 1999; Easterly et al. 1993; Rodrik 2006; Raddatz 2007; Allen and Giovannetti 2011; Berg et al. 2011). Financial globalization has further increased macroeconomic and capital flows volatility, especially in poor countries with underdeveloped financial markets (Prasad et al. 2007; Dell'Ariccia et al. 2008; IMF 2011c). The exposure to macroeconomic instability and capital flight might also be an endogenous result of large external debts (Alesina and Tabellini 1989; Cerra et al. 2008), which could partially explain the Lucas (1990) paradox of capital flowing perversely from poor to rich countries. The demand for liquidity by developing countries is well testified by their reliance on IMF lending facilities during the current global crisis, despite the cost of associated conditionalities, stigma effects, and the poor economic growth (Dreher 2006; Bird 2007; Presbitero and Zazzaro 2011).

The vulnerability of a country stems from three factors: 1) the size and frequency of exogenous shock, 2) the exposure to shocks, and 3) the capacity to react to shocks (Guillaumont 2011). In this context, monetary and exchange rate conditions play a major role for several reasons. First, the trade balance is strongly dependent on the exchange rate vis-a-vis the US dollar, given that the fragility of many LICs, at least those in Sub-Saharan Africa, depends on the concentration of export revenues in no more than three commodities and on their proclivity to import natural resources (Allen and Giovannetti 2011). Second, LICs, at least before the recent multilateral debt relief initiatives, tend to be heavily indebted, while the value of the stock of their foreign currency-denominated external public debt and debt service are sensitive to the exchange rate. Valuation effects are important also for the value of the increasing stock of international reserves.

The exposure to risks posed by exogenous shocks, as measured by the Economic Vulnerability Index (EVI), ${ }^{6}$ is higher in LICs than in middle and non-OECD high income countries (Fig. 2, left panel). The export instability index in LICs is $25 \%$

\footnotetext{
${ }^{5}$ The ratio of reserves to short term debt - a better indicator to assess the role of reserves as a precautionary assets in response to capital flows - is not reported because of poor data quality in several LICs, When this ratio is available, it provides findings similar to the ones discussed in the main text (IMF 2011a).

${ }^{6}$ EVI is a composite index consisting of seven indicators: population size; remoteness; exports concentration; the share of agriculture, forestry and fisheries in gross domestic product; homelessness owing to natural disasters; instability of agricultural production; and instability of exports of goods and services. For more details, see Guillaumont (2011).
} 

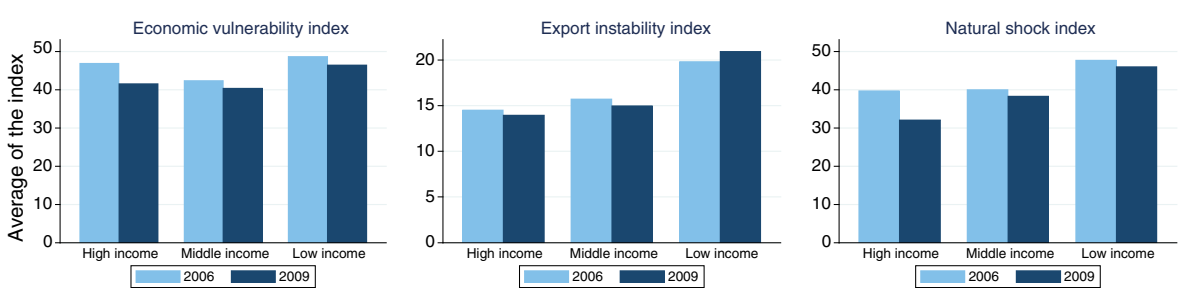

Fig. 2 Economic Vulnerability, 2006 and 2009. Notes: authors' elaboration on UN DESA - Committee for Development Policy data (available at: http://webapps01.un.org/cdp/dataquery/selectCountries.action; last retrieved: September 2011). The left-hand side diagram plots the Economic Vulnerability Index (EVI), while the other two diagrams plot two sub-components of the EVI

higher than in middle-income and industrialized countries (Fig. 2, central panel). The other main source of vulnerability is the exposure to natural shocks (Fig. 2, right panel).

The capacity to cope with exogenous shocks depends, among other things, on the level and composition of international reserves. In the current climate of global financial crises, developing countries have further increased the demand for international reserves. The IMF (2011b) estimates this increase in the range between $\$ 800-1,600$ billion over the period 2012-2016. It follows that a reformed IMS, where SDRs play a greater role, would mitigate exchange rate volatility, promote a diversification of reserve composition, reduce the opportunity cost of holding large amounts of international reserves and improve the external position of LICs (IMF 2011d; Obstfeld 2011).

\subsection{The Costs of Hoarding Reserves}

Reserve accumulation is generally due to two competing reasons: (1) the creation of a liquidity buffer to cope with capital outflows, terms of trade shocks and selffulfilling financial crises (Aizenman and Lee 2007), and (2) the necessity to avoid exchange rate appreciation due to "mercantilist" trade policies (Dooley et al. 2004). The current boom in reserve accumulation in developing countries is driven by selfinsurance motives, given that countries with more reserves have done better in smoothing domestic investment and absorption during the recent food and financial crisis (IMF 2011a). For indebted countries, reserve accumulation, reducing the probability of a sovereign default, lowers the sovereign spread over the risk-free return on reserve paid on the full stock of debt (Levy Yeyati 2008). Risk aversion has increased substantially, especially after the Latin American crisis of the early 1980s and the 1997 East Asian crisis. Financial openness and financial development have raised macroeconomic and systemic risks and have placed extraordinary demands on central banks' foreign exchange reserves (Obstfeld et al. 2010).

As mentioned, reserve hoarding implies a social cost, measured by the benefit the country could derive from an alternative use of funds, be that in the form of productive investment or expenditures on social programs. ${ }^{7}$ In a multi-country perspective, the accumulation of reserves invested by developing countries in short-term liabilities

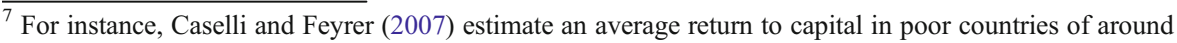
$7 \%$, compared with $0.3 \%$ yield on a one-year T-Bill.
} 
issued by key-currency countries (primarily the United States) stands as one of the flaws of the current IMS; it is known as the inequity bias (Ocampo 2010a; 2010b) and permits rich countries to be financed by poor countries at low interest rates. Reserve accumulation imposes also potential costs through exchange rate valuation losses and maturity mismatches between long-term foreign liabilities and short-term international reserves. Large reserve transactions may have destabilizing effects on interest rates and exchange rates, and thus raise systemic risks (Obstfeld 2011).

Rodrik (2006) calculates that the increase in reserves occurred in the early 1990s in developing countries (where reserves reached almost 30\% of GDP and 8 months of imports) has been translated in an income loss close to $1 \%$ of national GDP. The consideration of the benign effect of reserve accumulation on the sovereign debt spread could halve the marginal cost of reserve (Levy Yeyati 2008). In the new millennium, the average cost of reserves has been estimated to about $0.5 \%$ of GDP (IMF 2011a). Akyuz (2010) estimates that the annual cost of borrowed reserves for developing and emerging economies is about USD 130 billion, more than the total annual budget of official development assistance. ${ }^{8}$

In addition, the accumulation of reserves in the current IMS makes LICs even more dependent on the US dollar, fuelling macroeconomic imbalances and exposing poor countries to risks of large capital losses in case the US dollar sharply depreciates. Key currency countries, by borrowing at low interest rates, have incentives to run current-account deficits and accumulate debt. Moreover, the financial system may underprice overall risks because of low yields on reserve assets (IMF 2010d). In brief, "foreign-exchange reserves seem to offer an unfavourable risk-return trade-off" (Angeloni et al. 2011, p. 5).

\subsection{International Reserves Diversification and SDR Holdings}

The general sentiment in developing and emerging countries and the recent change in the currency composition of reserves suggests that developing countries are in fact expressing a demand for diversification. Lacking data on currency composition for single countries, the next best is to use the IMF COFER database to gain some understanding of recent trends. In 139 reporting countries, international reserves increased from almost $\$ 1,400$ billions in 1995 to more than $\$ 2,000$ billions in 2001 and to $\$ 9,258$ billions at the end of 2010 . During the same time period there has been a reversal in the relative weight of reserve accumulation between industrialized and emerging and developing countries, with the latter raising their weight from one third of the total amount in 1995 to two thirds in 2010 (Fig. 3, left panel); this trend is expected to continue (World Bank 2011).

At the same time, the share of US dollar-denominated reserves has slightly declined in the last decade, even if the dollar share has remained well above $60 \%$, suggesting the lack of any significant trend away from the dollar as a key currency (Fig. 3, right panel; Galati and Wooldridge 2009; Alessandrini and Fratianni 2009b; Benigno 2010). It is worth noting that US dollar shares held by advanced economies sharply increased up

\footnotetext{
${ }^{8}$ Alternative estimates suggest that the annual cost of owned reserves for developing countries, calculated as the difference between investing reserves in lower yielding US treasury bonds and higher yielding investments, is $\$ 300$ billion (Eurodad 2010).
} 

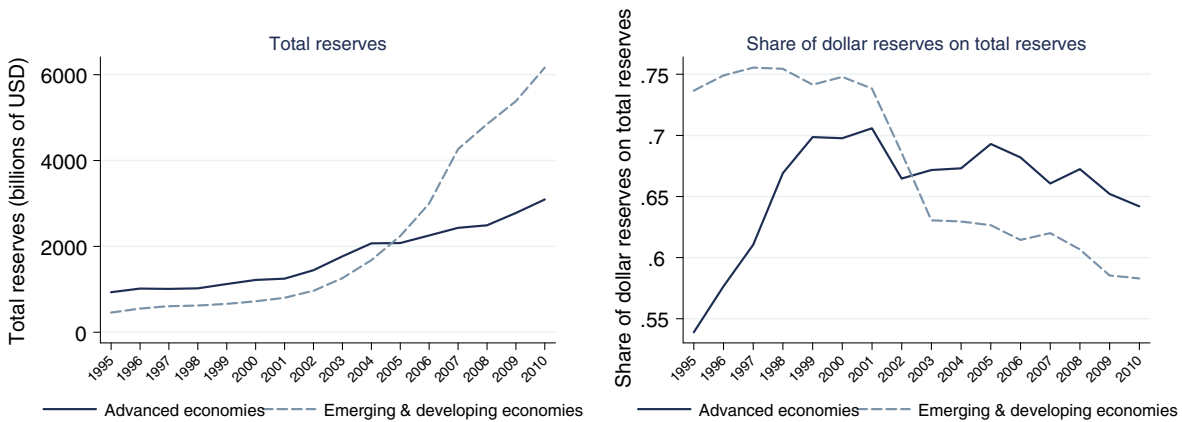

Fig. 3 International reserves in advanced and developing countries. Source: authors' elaboration of IMF data (http://www.imf.org/external/np/sta/cofer/eng/index.htm; last retrieved: September 2011)

to 2001, when they stabilized. By contrast, dollar shares in developing and emerging markets shrunk from $75 \%$ in the late 1990 s to less than $60 \%$ in 2009-2010. This trend, read together with the increasing holdings of US Treasury securities by China and oil exporting countries, suggests an underlying demand for currency diversification by poor and vulnerable countries. Given the colonial ties and the economic linkages between Africa and the European Union (Olivier 2011), the introduction of the euro has played a role in the currency composition of reserves. As to SDRs, their relative weight before 2009 was extremely low, then increased to about $7 \%$ at the end of 2009 . SDR shares are much more variable across countries and, on average, larger in LICs than in middle- and high-income countries (Fig. 4), suggesting that LICs have a potentially higher demand for currency diversification.

The lower dependence on the US dollar and a higher dependence on SDRs are more likely to happen in vulnerable countries. The positive correlation between SDR shares and the index of economic vulnerability for low, middle and non-OECD high-income countries suggests that the diversification of reserves away from key currencies and towards a currency basket is driven by precautionary motives, aimed at insuring against currency-driven shocks (Fig. 5). The positive correlation between SDR shares and vulnerability is partially offset in the sample of LICs by few countries, which have much larger SDR shares (over $20 \%$ of total reserves) than countries with a similar level of vulnerability. This subset of countries has a ratio of reserves to GDP lower
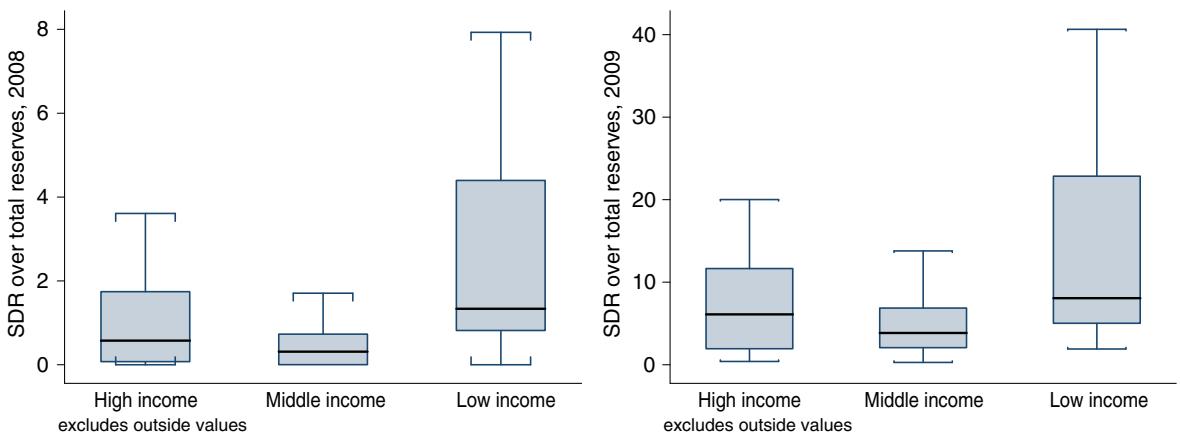

Fig. 4 SDR share in total reserves in 2008 and 2009, by countries' income levels. Notes: authors' elaboration on IMF (http://www.imf.org/external/np/fin/tad/extsdr1.aspx; last retrieved: September 2011) and World Bank (World Development Indicators) data 


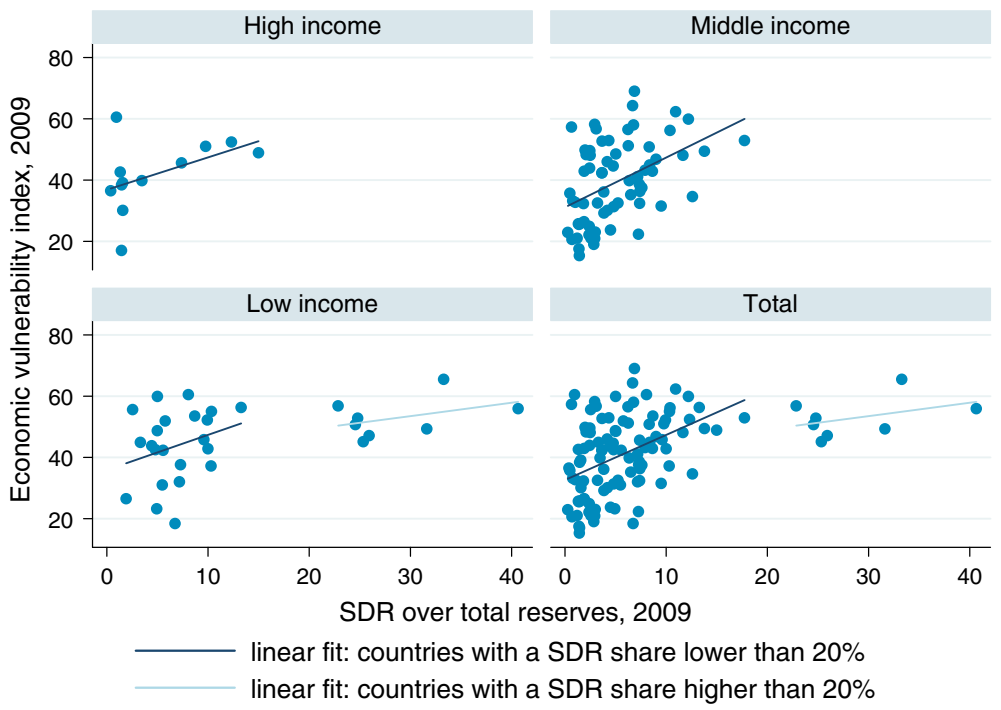

Fig. 5 SDR share in total reserves and economic vulnerability, by countries' income levels. Notes: authors' elaboration of IMF, World Bank (World Development Indicators) and UN DESA data. The Economic Vulnerability Index (EVI) is a composite index calculated by UN DESA - Committee for Development Policy (available at http:/webapps01.un.org/cdp/dataquery/selectCountries.action; last retrieved: September 2011. SDRs over total reserves are ratios (times 100) of SDR allocations to total reserves (including gold) in 2009

than the LIC average, while the ratio of current-account deficit to GDP is greater than the group average. ${ }^{9}$ Thus, large SDR shares in countries particularly exposed to external shocks can be explained by a lower capacity to accumulate US-denominated reserve assets, rather than by a higher SDR demand. In this case, additional SDR allocations could help filling the external financing gap.

The hypothesis that SDRs have been in fact a useful tool to cope with exogenous shocks is supported by the analysis of the uses of SDRs after the mentioned 2009 allocations. Out of 110 countries (with the exclusion of OECD economies), only 13 of them sold SDRs for an amount larger than 50\% of their allocations. And these countries are far poorer, more exposed to natural shocks, with a more concentrated export base and with a greater reliance on agriculture than countries that either sold a smaller share of SDR holdings or actually increased them (Table 1).

\section{The Recurrent Need of Reforming the IMS}

\subsection{The Inadequate old SDR Scheme}

Many reform proposals of the IMS were advanced in the past century. Two institutional milestones stand out to these days: the Bretton Woods Agreements of

\footnotetext{
9 Those countries are Burundi, Sierra Leone, Zambia, Central African Republic, Mauritania, Congo DR, Liberia and Malawi. According to WEO data, their average current account balance in 2008 was $-18.1 \%$ of GDP, while the average value for the other LICs was $-8.8 \%$. Similarly, their level of reserves was $10 \%$ of GDP, lower than the $14.9 \%$ of the other LICs.
} 
Table 1 Changes in SDR holdings, after the 2009 allocations, and economic vulnerability

\begin{tabular}{llll}
\hline & \multicolumn{2}{l}{$\begin{array}{l}\text { Change in holdings between September 30, 2009 and July 31, 2011 } \\
\text { (percentage values) }\end{array}$} \\
\cline { 2 - 4 } & $-50 \%$ or less & negative changes, up to 50\% & Positive \\
\hline Economic Vulnerability Index & 43.8 & 40.9 & 41.7 \\
Export concentration & 0.472 & 0.442 & 0.437 \\
Agricultural concentration & 20.8 & 16.8 & 18.2 \\
Natural shock index & 42.5 & 40 & 37.5 \\
GNI per capita (USD) & 2,170 & 3,600 & 8,546 \\
Number of countries & 13 & 73 & 24 \\
\hline
\end{tabular}

Authors' elaboration of IMF and UNDESA data. The Economic Vulnerability Index (EVI) is a composite index calculated by UN DESA - Committee for Development Policy (available at: http://webapps01.un. org/cdp/dataquery/selectCountries.action; last retrieved: September 2011). Export concentration is measured as Herfindahl-Hirschman indices derived from three-digit SITC product categories; agricultural concentration is the share of agriculture, forestry and fisheries in GDP; the natural shock index takes into account the percentage of homeless and an index of agricultural instability. All measures, including GNI per capita refer to 2009. For additional details, see: http://www.un.org/en/development/desa/policy/cdp/ ldc/ldc_definitions.shtml\#evi; last retrieved: September 2011)

1944 and the IMF Annual Meeting in Rio de Janeiro of 1967. The former established the gold-dollar exchange standard, while the latter introduced the SDRs as a net addition to international reserves. This solution was made necessary by the intrinsic instability of the Bretton Woods system, as stated by the Triffin (1960) dilemma, according to which the key currency issuing country can not supply money for domestic needs and at the same guarantee availability, convertibility and confidence in its currency as international money in the long run. The Bretton Woods system collapsed because the United States terminated unilaterally the gold convertibility of the dollar in 1971. That decision was made in rough coincidence with the first allocation of SDR 9.3 billion, distributed between 1970 and 1972.

The SDR distribution, together with the lessons emanating from the Committee of Twenty on the Reform of the International Monetary System, could have been taken as an opportunity to bring the SDRs at the center of the IMS. Instead, the discussions inside the Committee of Twenty revealed the difficulty of the SDRs to reach their target of "supplement[ing] existing reserve assets" and "avoid[ing] economic stagnation and deflation as well as excess demand and inflation in the world" (IMF 2011e, Articles of Agreement, XV, section 1(a) and XVIII, section 1(a)). The result was that the dollar continued to be the dominant currency, gold lost importance, and the SDRs were emarginated by their operational and quantitative restrictions (Bordo and James 2012, in this issue). Over the years, the dollar standard softened somewhat first by the shift towards more flexible exchange rates (Obstfeld and Rogoff 1995) and, much later, by the birth of the euro.

While the international monetary framework has changed substantially since Bretton Woods, the concerns about the instability of the IMS and the need for reforms are still those that preoccupied the minds of the drafters of the Bretton Woods agreements and the SDR initiative: namely, providing the IMS with a supernational money to 
supplement existing reserve assets and to solve the target of stabilizing the global economy. The elimination of the gold convertibility of the dollar did not solve the Triffin dilemma. As expected, the external position of the United States progressively deteriorated; in the process, US monetary leadership weakened. Yet, no other national currency proved to have the characteristic to replace the dollar as the dominant key currency (Pittaluga and Seghezza 2012, in this issue). The euro has become the second most important currency in international trade and in the financial markets, but the Eurosystem is badly debilitated by an incomplete institutional integration and by excessive levels of public debt. The yen and the pound have a marginal role in international trade, a situation somewhat similar to the currencies of the new creditor countries, like the Chinese yuan, that still lacks full convertibility (Galati and Wooldridge 2009; Bank of International Settlements 2010).

The issue of a supernational money is once again at the center of the policy discussion. There is an inverse correlation between the strength of the US dollar as a dominant currency and the pressure to find an agreement on a fiduciary supernational money. When the dollar is strong, proposals for a supernational money are not taken seriously; it happened with the Keynes Plan (1943) at Bretton Woods, the Triffin Plan (1960), and the Ossola Commission (Group of Ten 1965). The latter was appointed in 1964 with the objective to reform the gold-dollar system. After three years of discussion the Commission, as a compromise solution, could only agree on the creation of the SDRs. It is not surprising that with the current weakening of the dollar standard, the attention is focusing again on the principles which inspired the Keynes Plan and on the desirability to improve the SDR scheme by relaxing the constraints that have made such scheme ineffective so far.

Even before it got started, it was evident that the SDR scheme had been over constrained (Machlup 1968). The definition by the IMF makes it clear that: "SDR is neither a currency, nor a claim on the IMF. Rather, it is a potential claim on the freely usable currencies of IMF members ". ${ }^{10}$ Each central bank is entitled to transfer SDRs to a corresponding central bank in exchange of an equivalent value of a national currency, needed to intervene in the exchange market. Therefore, instead of introducing a new supernational money, the SDRs simply allow bilateral transactions with the only purpose of activating national key currencies. For this reason, Machlup (1968) considered the SDR scheme merely a "giro system". Moreover, contrary to its mission of replacing an excessive amount of dollars, the SDR scheme actually achieved the opposite result of activating more dollars in the system.

\subsection{The Difficult Road to Improve the SDRs}

Proposals to strengthen the mechanics of the SDRs go back to the early Seventies. Hirsch (1973) advocated several improvements, such as: regular annual allocations, a specific allocation to the World Bank to be used for development aid, the creation of a substitution account to reduce an excessive accumulation of dollars, symmetrical currency intervention through a clearing system, and the introduction of an overdraft facility. Steps toward a more comprehensive SDR system were tried in the Seventies. Two initiatives, proposed by the Committee of Twenty in 1974 and

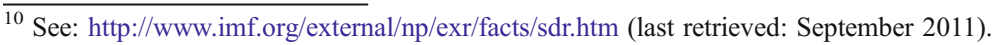


renewed by the Interim Committee of the IMF in 1978-1979, which would have allowed central banks to replace part of their dollar reserve assets in a substitution account denominated in SDRs at the IMF, never came to light because of the opposition of the United States and the IMF Board to share the corresponding exchange rate risk (Kenen 1981; Micossi and Saccomanni 1981; Boughton 2001). Aid link proposals for a disproportionate allocation of SDRs to poor countries were not successful either, especially because of fears of global inflation and of the loss of control on international aid by national legislators, creating a missing opportunity to help poor countries (Grubel 1972; Maynard 1973; Helleiner 1974; Bird and Maynard 1975). The Seventies ended with a second allocation of SDR 12.1 billion. Since then, the SDRs have been almost forgotten. In 2008, the SDR share in international reserves fell to less than 0.5\% (Williamson 2009; Obstfeld 2011). Given that SDRs are allocated to IMF member countries in proportion of their quotas, LICs own less than one SDR billion, or $4.2 \%$ of the total SDR 21.4 billion.

The recent SDRs revival was advocated by the Governor of the People's Bank of China Zhou Xiaochuan (2009), who influenced the decision taken at the 2009 London G20 meeting to create SDR 204 billion. The mechanics of the new creation followed old patterns: that is, a once-for-all supply based on countries' IMF quotas and subordination to the use of national currencies. That notwithstanding, the door has been opened or reopened for a serious reconsideration of the IMS reform based on an expanded role of SDRs (Williamson 2009; DeAnne 2010; Kenen 2010a; 2010b; Ocampo 2010a, b Padoa Schioppa 2010; IMF 2011d). Xiaochuan's policy position is very significant in several points. First, it officially confirms that the greatest creditor country in the world has no ambition of monetary leadership, at least in the medium term. Second, it reveals China's anxieties about a dollar standard crisis and the urgency to diversify its international reserves away from dollar assets. Third, it signals that China favours concrete steps toward the establishment of a supernational money standard. Xiaochuan recommends specific improvements to transform SDRs into a true supernational money, such as the SDRs being booked as a liability of the issuing institution, backed by assets, and exchanged through a settlement system among central banks.

The reforms advocated by Xiaochuan are not new. They echo numerous old plans for the centralization of international monetary reserves. ${ }^{11}$ The call for a higher degree of supernational monetary management has not changed after more than half a century. The size of the problem today is certainly larger than it was back then. Hence, the renewed urgency not to further delay the reduction of national currency asymmetries and reduce the risk of an implosion of the dollar standard, with a consequent global monetary crisis.

\section{A Feasible New SDR Scheme in a Multi-Currency System}

We discuss in this section a plan for an expanded role of the SDRs with the goal of strengthening the existing IMS. The biggest challenge one faces in such a task is to

\footnotetext{
11 "What all these plans, beginning with the Keynes Plan and including all other prototypes and variant, have in common is that an international financial institution is charged with the function of creating through the acquisition of claims or other assets (or fictitious assets) - additional deposit liabilities that would be accepted by the central banks as part of their monetary reserves" (Machlup 1966, p.335).
} 
calibrate the trade-off between monetary supernationality and the retention of national sovereignty. How can one construct a system of supernational money management without substantially decreasing the scope of national sovereignty? The best compromise is obtained by applying the five principles that inspired the Keynes Plan of 1943: gradualism, the banking approach, multilateralism, complementarity and symmetry of adjustment; see Alessandrini and Fratianni (2009a). Gradualism is a feature shared by all recent reform plans. Gradualism does not represent an obstacle to an ambitious plan; it acknowledges the advantage of proceeding step-bystep. On this ground, our approach is eclectic, open to gradual expansion as result of learning by doing and to the new opportunities afforded by the evolution of events. In what follows, we will outline how these principles apply to our proposal for a feasible new-SDR scheme.

\subsection{Exogenous and Endogenous Creation of SDRs}

The aim of the new scheme is the realization of a multi-currency system in which the SDRs play a significant role as a supernational money. Under this framework, there would be two alternative channels for SDR creation, one exogenous and the other endogenous. The former is what we have now, which works through the creation of a predetermined quantity of SDRs. Each central bank registers on both sides of the balance sheet the amount of assigned SDRs. The same values are booked, with opposite sign, on the IMF balance sheet. In the old scheme, these were fictitious assets and liabilities, and the Fund passively registered the exchanges of SDRs for national currencies between central banks. In the new-SDR scheme, we envision this channel to be managed in a flexible way for stabilization and development purposes.

To achieve a greater degree of supernationality, it is necessary to add an endogenous channel of SDR creation to the existing framework. There are two ways to do it: an overdraft (OD) and a substitution account (SA). With the former, the SDRs acquire an important credit function, in line with Keynes' banking principle and supernational bank money discussed in his Treatise (1930) ${ }^{12}$ and in his Plan (1943), and reaffirmed by Triffin (1960) and others. ${ }^{13}$ The OD facility is often overlooked in current proposals (Zhou 2009; Bird 2010; DeAnne 2010), ${ }^{14}$ probably because of concerns about inflationary bias and governance issues, which are discussed below. Our position, instead, is that the OD facility would soften the burden of adjustment of external imbalances, and redistribute international money towards LICs.

The SA facility, the mechanism to exchange foreign currency reserve assets for SDR-denominated claims, has re-gained momentum in the current reform proposals (Kenen 2010b), under the stimulus of reducing the large stock of dollar reserve assets owned by the central banks of creditor countries. Being endogenously created,

\footnotetext{
12 Alessandrini and Fratianni (2009a) use supernational bank money as the basis for IMS reform.

13 See Grubel (1963). Inside the Fund, Polak (1979) proposed a mechanism through which the IMF could create (temporary) additional financing during balance of payments crisis. More broadly, Polak's goal was to eliminate the role of national currency holdings altogether and re-create the IMF as a financial institution based solely on the SDRs as a financing technique (Boughton 2011).

${ }^{14}$ An exception is the scheme proposed by Ocampo (2010b), in which the overdraft drawing facility is discussed as an ambitious instrument to reduce the asymmetries of the IMS. According to Ocampo, the overdraft facility could be used by IMF member countries unconditionally and for a fixed period of time.
} 
the SDRs would graduate from a "potential claim" to use national currencies to an active role of main reserve asset in the IMS and a possible substitute of national currencies. In this way, the new SDR-denominated claims would alter in a significant way the portfolio allocation of central banks international reserves.

The OD and SA facilities would add a demand-driven component to the SDR creation. There are differences between the two facilities. The OD facility would add to international liquidity in the same way that a domestic standing facility does for domestic liquidity. The SA facility, instead, would simply alter the composition of international liquidity: SDRs are created with a simultaneous destruction of reserve assets denominated in national currencies.

In both cases, the creation of SDR-denominated deposits raises the degree of supernationality and the diversification of international reserve assets. For poor countries, the additional liquidity created through the OD facility would attenuate the external constraint; the potential long-term benefits of the new SDR allocations would depend on different import strategies (Bird 2010). The ability to borrow reserves would allow countries with balance-of-payments deficits to take more time to find the right adjustment policy, with less pressure to adopt either penalizing restrictive policies or controversial exchange rate devaluations. It should be pointed out that the OD facility could generate moral hazard behavior, inflationary pressures and, should international reserves finance public investment, would transform the IMF into a development agency.

\subsection{New SDR Allocation and Use}

Under the new scheme, each central bank would have an SDR-denominated account at the IMF and access to an overdraft facility. In order to meet poor countries' financing and development needs, the allocation of supply-driven SDRs would be based on an aid link and/or go hand-in-hand with a reform of IMF quotas towards an increased multilateralism.

SDR-denominated deposits would be used to settle payments between central banks. As an example, the central bank of a surplus country like China would buy foreign currency (dollars) in exchange for national currency to avoid an exchange rate appreciation, and then decide to convert dollar-denominated reserves into SDRs. This would be done first selling US T-Bonds in the open market (the funds obtained would be booked in the deposit account of the People's Bank of China at the FED), and later asking the FED to convert dollars into SDRs. The IMF would act as a clearing house. At the end of the process the People's Bank of China would have more SDR-denominated deposits, and the FED a corresponding reduction of SDRdenominated deposits. Moreover, were FED deposit availability insufficient, an OD facility would be activated. ${ }^{15}$

The use of a supernational money in a multi-currency system has three important implications. First, it introduces the multilateral principle: the debit/credit relationships between central banks are no longer exclusively bilateral; they become multilateral through the clearing system managed by the Fund. Second, according to the principles of gradualism and complementarity, the new SDRs are not imposed as

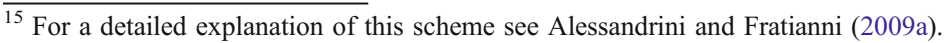


the only international reserve assets; they would be freely chosen by central banks as an alternative to reserve assets denominated in the key currency. Third, the creation of the new SDRs would mitigate the anti-Keynesian bias (Ocampo 2010a; 2010b), that is the asymmetry, now present, in the adjustment undertaken by deficit and surplus countries. Continuing with our US-China example, the Chinese choice of accumulating SDR-denominated reserves (instead of US dollar assets) would imply a reduction in the US monetary base. The exorbitant privilege of the country issuing the key currency would be eliminated, since the use of a supernational money would impose an external monetary constraint also for the center country. The Triffin dilemma would automatically be solved (Alessandrini and Fratianni 2009a; 2009b). As a consequence, the US external position would become similar to LICs' structural deficit, and the instability-inequity bias would be reduced (Ocampo 2010a).

Given that the value of the new SDRs would be determined by a currency basket, ${ }^{16}$ the value of SDR-denominated loans would be more stable than singlecurrency loans. This would reduce the vulnerability of poor countries to exchange rate swings, especially in the case of an SDR peg, and lower the precautionary demand for costly dollar-denominated reserves. The same condition would apply to SDR-denominated deposits, whose value would be more stable and thus would reduce volatility in the reserve portfolio of creditor central banks.

\subsection{Supernational Governance}

The establishment of new channels, through which SDRs can be created and distributed, would be an opportunity to reform the governance of the IMS. Any reform, however, should be gradual and follow the convergence of the preferences of the leading central banks.

At the centre of the reform proposal there is the role of the Fund. Our proposal would give a leading role to the Fund. Relying on the banking principle, the IMF would acquire two typical banking functions: a monetary one, thanks to the new SDR-denominated deposits, and a credit function, thanks to the OD facility.

The most important concern about our plan is that the OD facility may be subject to an inflation bias. Similar considerations were expressed when Keynes and Triffin wrote their plans and were discussed during the long phase of SDR creation, especially on the European side. However, this concern may be overstated for two reasons. The first stems from the very nature of the currency basket, whose value is determined by the quantities of the participating currencies and exchange rates. The interest rate on SDR-denominated deposits, and ultimately the interest rate that the IMF would charge on the OD, would be the weighted average of the national policy rates of the participating countries. These countries have a solid anti-inflationary reputation, which would be transmitted to the new SDRs. In this sense, the IMF would act passively in relation to national monetary sovereignty. The second is that the IMF could be given the authority to set incremental quantitative ceilings on the

\footnotetext{
${ }^{16}$ As in the existing system, the value of the new SDRs would be determined by a basket of the most important currencies: the US dollar, the euro, the Japanese yen, and the pound sterling, weighted by their respective shares in the global trading and financial systems. In the next future, to increase the SDRs attractiveness, currencies of other emerging markets could be added to the basket, such as the yuan, once fully convertible (IMF 2011d).
} 
OD, with increments based on higher levels of conditionality, should central banks of participating countries pursue a loose monetary policy.

A second concern is about the possible risks of moral hazard. These could be attenuated by ex-post credible sanctions when SDRs are exogenously allocated. Differently, when SDRs are created through the OD facility, they would be made available unconditionally up to a certain threshold level (partial unconditionality), above which policy conditionality and higher interest rates on the outstanding loan would attenuate moral hazard.

\subsection{Degrees of Discretion Assigned to the IMF}

Additional discretion could be given to the Fund in managing international liquidity in a counter-cyclical manner: during recession, exogenous allocations of SDRs could be larger and the access to the overdraft facility made easier, and the opposite during expansion. An even higher dose of discretion could be given to the IMF to compensate temporary shocks with appropriately larger or smaller fresh exogenous allocations of SDRs and compensatory changes in the unconditional OD limit and in collateral requirements. However, collateral standardization may be difficult when one deals with strongly heterogeneous countries, especially considering the low level of financial development in LICs. In these cases, the IMF could grant access to the OD facility only if the requesting country accepts to participate in investment and development policy operations financed by the World Bank or by one of the regional development banks.

The IMF acquisition of foreign currency-denominated assets, with corresponding liabilities in the form of SDR-denominated deposits, creates an exchange rate risk. Under the new scheme, the IMF Executive Board would decide whether to bear the exchange rate risk or to sell the foreign currency assets to the respective central banks in exchange for SDRs. The latter decision imposes a constraint on the country's monetary policy, including the key currency country, and enforces symmetry in the external adjustment burden. On this ground, one should adhere the general rule advocated by Keynes in his Plan: deficit countries should bear the adjustment burden in periods of global inflation; in global recessions the burden of adjustment should fall on surplus countries, through expansionary policies. The difficulties to implement this principle are an old problem and are discussed by Williamson (2012, in this issue).

\section{The New SDR Scheme in the International Aid Framework}

In order to devise sensible proposals for easing the external financing constraints of LICs, two aspects must be analysed. The first is the institutional feasibility of the scheme, which would involve a transformation of the IMF original mission along the lines described above; the implications of this issue, however, goes beyond the scope of this paper. The second is the trade off between the potential advantages of the new SDR scheme with respect to the current framework under which foreign assistance is granted and the costs are borne by donors.

As regard the benefit side of the trade off, the choice of allocating a disproportionate share (relative to IMF quota) of SDRs to LICs has to be assessed 
in the context of the aid effectiveness debate. The restoration of the SDR aid link envisaged in the proposed scheme or the extension of the unconditional OD facility, in fact, would be another way to give LICs foreign assistance to ease their external constraint and/or to finance development projects.

According to a growing consent in the development literature on the ineffectiveness of foreign aid in triggering investment and growth in recipient countries (Rajan and Subramanian 2008; Doucouliagos and Paldam 2009), an increase in international aid might not be the most efficient solution. Nevertheless, some scholars are raising dissenting voices, suggesting that aid has a positive and statistically significant causal effect on growth over the long run (Arndt et al. 2010; Minoiu and Reddy 2010). More specifically, it has been shown that the efficiency of donor agencies is highly heterogeneous (Easterly and Pfutze 2008; Easterly and Williamson 2011) and that the impact of aid is heterogeneous across donors, depending on their geo-strategic interests (Headey 2008). For instance, Bobba and Powell (2007) show that aid provided to political allies is ineffective for growth, whereas aid extended to countries that are not allies is highly effective. Similarly, bilateral aid from Nordic countries, whose lending is generally allocated to poorer countries and is free from self-interest considerations, has been shown to have a robust and long-run effect on GDP growth (Minoiu and Reddy 2010). In addition, also the mode of delivery matters (Ouattara and Strobl 2008), at least for some aspects, such as short-run growth (Clemens et al. 2004) and bureaucratic quality (Selaya and Thiele 2011).

If this is the case, the expansion of the exogenous and endogenous SDR supply channels, if properly linked to economic objectives and external imbalances, could deliver aid more efficiently than traditional bilateral or multilateral conditional assistance (Grubel 1972), in line with the principles of ownership, harmonization and alignment outlined by the Paris Declaration on aid effectiveness, endorsed in 2005 by more than 100 countries and development agencies.

- First, the SDR aid link could qualify as developmental assistance and overcome the objections related to policy-driven aid, which still matters for IMF concessional lending (Barro and Lee 2005; Barnabeck Andersen et al. 2006; Presbitero and Zazzaro 2011). ${ }^{17}$

- Second, as an automatic budget support instrument provided by a multilateral institution, the new SDR scheme would avoid the negative effects of donor fragmentation on the quality of government's bureaucracy (Knack and Rahman 2007).

- Third, by providing a predictable line of credit to fill the external financing gap, the scheme would limit the adverse effect of aid volatility on growth (Robe and Pallage 2001; Bulir and Hamann 2008; Kodama 2012). In this respect, the new SDR scheme partially mimics the Flexible and Precautionary Credit Lines recently established by the Fund to provide fresh money before the onset of a crisis without the standard ex-post policy conditionality. The new SDR scheme would be superior to the existing lending arrangements, since it would require neither a Washington consensus-like conditionality (up to a threshold level), nor ex-ante qualification criteria, which reduce the pool of potential applicants.

\footnotetext{
${ }^{17}$ The influence of industrialized nations in international organizations, like the World Bank, in fact, was one of the reasons why the aid-link channelled through development agencies was originally unsuccessful in gaining wide support (Maynard and Bird 1975).
} 
- Finally, assistance provided through the new SDR scheme could be considered as conditional budget support, since the costs/penalties associated with a structural deficit position should force countries to pursue structural reforms to correct their external imbalances. In this respect, the poor economic performance of conditional loans and structural adjustment programs (Morrissey 2004; Easterly 2005; Dreher 2006) calls for a radical re-design of the incentives for recipient countries; governments, and their donors, should set policies to aim at more sustainable current and fiscal balances in order to reduce global imbalances and the demand for costly precautionary reserves.

On the cost side of the trade-off, we have so far pointed out the potential inflationary bias and moral hazard of the scheme. In addition, one has to consider the proposal from the donors' perspective. The scheme envisages some room for policy conditionality to contrast moral hazard and to be politically acceptable by donors. However, without any additionality, a larger share of the bilateral aid budgets should be channelled through the Fund and then allocated unconditionally (up to a threshold). Thus, major bilateral donors, whose aid allocation is mainly driven by strategic, political and economic interests (Alesina and Dollar 2000), ${ }^{18}$ will lose part of their discretionary power. Realistically, this solution would be hardly opposed by rich countries. Nonetheless, the shift from bilateral aid to the new SDR scheme could also bring benefits to donor countries, in terms of reduced macroeconomic imbalances. While bilateral (untied) aid might be absorbed internally, without affecting the deficit of the balance of payments, SDRs would be explicitly targeted to reduce external disequilibria, fostering a global demand for goods and contributing to the overall stability of the IMS. The partial unconditionality would force recipient countries to undertake structural adjustments, allocating more resources to pro-growth expenditures, in order to close the external gap.

That the new SDR scheme points to a feasible but difficult to reach target is suggested by the pledges of major donors to improve aid effectiveness and also by the recent positions expressed by the US administration on foreign aid policy, which include positive and negative signals (Veillette 2011). Among the former, there is a significant increase in the share of multilateral aid (programmed at $10.2 \%$ of total aid budget in 2012), even if its relative weight is still limited compared with bilateral aid. On the negative side, limited progresses have been made so far in enhancing the role of development aid, whose share is losing ground relative to national security issues.

\section{Concluding Remarks}

The global financial crisis, the weakening role of the dollar and the increasing importance of new creditor countries call for a reform of the international monetary system towards greater multilateralism. In the current system, development finance to LICs is hampered by the extreme vulnerability of poor countries to exogenous shocks and by large stocks of international reserves. This situation imposes significant costs on the budget of poor countries and magnifies the global imbalances, creating an inequity-instability bias (Ocampo 2010a).

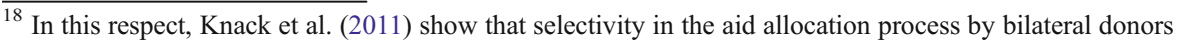
is generally worse than when aid is disbursed by the IMF.
} 
In this paper we have linked IMS fragility and LICs' vulnerability to justify a profound reform of the IMS. The key element of the reform is a revitalization of SDRs, called the new SDRs, that would become a true supernational money.

The main features of the new SDR scheme are summarized as follows:

1. The new SDRs would be managed actively by the IMF.

2. New SDRs would be created exogenously by the IMF and endogenously by countries either desiring to borrow SDRs from the IMF or replacing reserve assets denominated in national currencies with SDRs. The endogenous creation of SDRs can be subject to quantitative ceilings.

3. The very nature of the SDRs as a currency basket is such that the interest rate on SDR-denominated deposits is linked to the policy rates set by those national central banks whose key currencies enter in the basket. It follows that the reputation of the SDRs stems to a large extent from the reputation of the "participating" national central banks, and that the discretionary power of the IMF is limited.

4. The fact that the SDRs operate in a multicurrency system reduces the cost of accepting this reform by all key currency countries. National key currencies would coexist with SDRs and their relative weights would be demand driven. The new system is perfectly consistent with either the dollar remaining the dominant key currency or another national currency replacing the dollar as the leading international currency.

5. Monetary policy adjustments to external imbalances under the new SDR scheme would be symmetric. Unlike today, the dominant key currency country would face the same constraints as other countries.

6. Under the new SDR scheme, the IMF would be authorized to allocate a disproportionate (relative to IMF quotas) share of SDRs to poor countries. These "generous" allocations are justified as follows:

a. they would generate a direct benefit to the poor countries by easing their external constraint and by providing development finance for MDGs and a scaling-up of public investment in infrastructures;

b. they would generate an indirect benefit to the poor countries through the mechanism of a more stable IMS, which, in turn, would result in a lower demand of precautionary reserves, a smaller dependence on the dollar, and a reduced vulnerability to external shocks;

c. they would improve aid effectiveness relative to the existing foreign assistance framework: coordinated, unconditional (at least up to a threshold) and predictable assistance would avoid or mitigate several of the flaws of standard aid assistance, such as donor fragmentation, political influence, and volatility.

Open Access This article is distributed under the terms of the Creative Commons Attribution Noncommercial License which permits any noncommercial use, distribution, and reproduction in any medium, provided the original author(s) and source are credited.

\section{References}

Aizenman J, Lee J (2007) International reserves: precautionary versus mercantilist views, theory and evidence. Open Econ Rev 18(2):191-214 
Akyuz Y (2010) Policy responses to the global financial crisis: key issues for developing countries. In: Sundaram JK (ed) Reforming the international financial system for development. Columbia University Press, New York

Alesina A, Dollar D (2000) Who gives foreign aid to whom and why? J Econ Growth 5(1):33-63

Alesina A, Tabellini G (1989) External debt, capital flight and political risk. J Int Econ 27(3-4):199-220

Alessandrini P, Fratianni M (2009a) Resurrecting Keynes to stabilize the international monetary system. Open Econ Rev 20(3):339-358

Alessandrini P, Fratianni M (2009b) Dominant currencies, special drawing rights, and supernational bank money. World Economics 10(4):45-67

Allen F, Giovannetti G (2011) The effects of financial crisis on Sub-Saharan Africa. Review of Development Finance 1(1):1-27

Andersen B, Thomas H, Tarp F (2006) On US politics and IMF lending. Eur Econ Rev 50(7):1843-1862

Angeloni I, Bénassy-Quéré A, Carlton B, Destias C, Darvas Z, Pisani-Ferry J, Sapir A, Vallée S (2011) Global currency for tomorrow: a European perspective, Bruegel Blueprint, $n^{\circ} 13$, Brussels

Arndt C, Jones S, Tarp F (2010) Aid, growth, and development: have we come full circle?, Journal of Globalization and Development, 2(1), Article 5.

Arnone M, Presbitero AF (2010) Debt relief initiatives - policy design and outcome. Ashgate, Farnham

Aryeetey E (2004) A development-focused allocation of the special drawing rights, Discussion paper, $n^{\circ}$ 2003/3, WIDER.

Bank of International Settlements (2010) Triennial central bank survey of foreign exchange and derivatives market activity in 2010. BIS, Basel

Barro RJ, Lee J-W (2005) IMF programs: who is chosen and what are the effects? J Monet Econ 52 (7):1245-1269

Benigno G (2010) Challenges for the dollar as a reserve currency. In: Subacchi P, Driffill J (eds) Beyond the dollar: rethinking the international monetary system. Chatham House Report, London, Chatham House

Berg A, Papageorgiou C, Patillo C, Schindler M, Spatafora N, Weisfeld H (2011) Global shocks and their impact on low-income countries: lessons from the global financial crisis, IMF working paper, $n^{\circ} 11 / 27$

Bird G (1979) The benefits of special drawing rights for less developed countries. World Dev 7(3):281290

Bird G (2007) The IMF: a bird's eye view on its role and operations. J Econ Surv 21(4):683-745

Bird G (2010) The SDR aid link: it's now or never. Development Policy Review 28(1):63-74

Bird G, Maynard G (1975) International monetary issues and the developing countries: a survey. World Dev 3(9):609-631

Bobba M, Powell A (2007) Aid and growth: politics matters, RES working papers, $\mathrm{n}^{\circ} 4511$, interAmerican development bank

Bordo MD, James H (2012) Reserves and baskets, open economies review, in this issue

Boughton J (2001) Silent revolution: the international monetary fund 1979-1989. International Monetary Fund, Washington, D.C

Boughton J (2011) Jacques J. Polak and the evolution of the international monetary system. IMF Economic Review 59(2):379-399

Bulir A, Hamann JA (2008) Volatility of development aid: from the frying pan into the fire? World Dev 36 (10):2048-2066

Caselli F, Feyrer J (2007) The marginal product of capital. Q J Econ 122(2):535-568

Cerra V, Rishi M, Saxena S (2008) Robbing the riches: capital flight, institutions and debt. The JJournal of Development Studies 44(8):1190-1213

Clark PB, Polak JJ (2004) International liquidity and the role of SDR in the international monetary system. IMF Staff Pap 51(1):49-71

Clemens M, Radelet S, Bhavnani R (2004) Counting chickens when they hatch: the short-term effect of aid on growth, CGD working papers, $\mathrm{n}^{\circ} 44$, center for global development

DeAnne J. (2010) A road map for SDR evolution, in Subacchi, P. and Driffill, J. (eds.), Beyond the dollar. rethinking the international monetary system, a Chatman house report, March, 36-42

Deaton A (1999) Commodity prices and growth in Africa. J Econ Perspect 13(3):23-40

Dell'Ariccia G, di Giovanni J, Faria A, Kose AM, Mauro P, Schindler M, Terrones M, Ostry JD (2008) Reaping the benefits of financial globalization, IMF occasional paper, $n^{\circ} 264$

Dooley MP, Folkerts-Landau D, Garber P (2004) The revived Bretton Woods system. Int J Finance Econ 9 (4):307-313

Doucouliagos H, Paldam M (2009) The aid effectiveness literature: the sad results of 40 years of reserach. J Econ Surv 23(3):433-461 
Dreher A (2006) IMF and economic growth: the effects of programs, loans, and compliance with conditionality. World Dev 34(5):769-788

Easterly W (2005) What did structural adjustment adjust. the association of policies and growth with repeated IMF and world bank adjustment loans. J Dev Econ 76(1):1-22

Easterly W, Pfutze T (2008) Where does the money go? best and worst practices in foreign aid. J Econ Perspect 22(2):29-52

Easterly W, Kremer M, Pritchett L, Summers LH (1993) Good policy or good luck?: country growth performance and temporary shocks. J Monet Econ 32(3):459-483

Easterly W, Williamson CR (2011) Rhetoric versus reality: the best and worst of aid agency programs. World Dev 39(11):1930

Eurodad (2010) The cost of reserves, January, Eurodad

Galati G, Wooldridge P (2009) The euro as a reserve currency: a challenge to the pre-eminence of the us dollar? International Journal of Finance \& Economics 14(1):1-23

Group of Ten (1965) Report of the study group on the creation of reserve assets, Group of ten

Grubel HG (ed) (1963) World monetary reform. plans and issues. Oxford University Press, London

Grubel HG (1972) Basic methods for distributing special drawing rights and the problem of international aid. J Finance 27(5):1009-1022

Guillaumont P (2011) The concept of structural economic vulnerability and its relevance for the identification of the least developed countries and other purposes (nature, measurement, and evolution), CDP Background Paper No. 12, United Nations

Headey DD (2008) Geopolitics and the effect of foreign aid on economic growth: 1970-2001. J Int Dev 20(2):161-180

Helleiner GK (1974) The less developed countries and the international monetary system. J Dev Stud 10 (3-4):347-373

Hirsh F (1973) An SDR standard: impetus, elements, and impediments, essays in international finance, Princeton University, n.99, June

IMF (2010a) Malawi: staff report for 2009 Article IV consultation and request for a 3-year Arrangement under the extended credit facility, IMF Country report, No. 10/87

IMF (2010b) Islamic republic of Mauritania: 2009 Article IV consultation and request for a 3-year arrangement under the extended credit facility — staff report, IMF country report, No. 10/168

IMF (2010c) Central African republic: staff report for the 2009 article IV consultation and fifth review under the arrangement under the poverty reduction and growth facility, requests for waiver of nonobservance and modification of performance criteria, and financing assurances review-staff report, IMF country report, No. 10/21

IMF (2010d) Reserve accumulation and international monetary stability, international monetary fund, April 13

IMF (2011a) Assessing reserve adequacy, international monetary fund, February 14

IMF (2011b) The case for a general allocation of SDRs during the tenth basic period, international monetary fund, June 10

IMF (2011c) Managing volatility: a vulnerability exercise for low-income countries, international monetary fund, March 9

IMF (2011d) Enhancing international monetary stability - a role for the SDR?, international monetary fund, January 7

IMF (2011e) Articles of agreement of the international monetary fund (1944), International monetary fund, Washington, D.C

Kenen PB (1981) The analytics of a substitution account. BNL Quarterly Review 139:403-426

Kenen PB (2010a) Reforming the global reserve regime: the role of a substitution account. International Finance 13(1):1-23

Kenen PB (2010b) A SDR based reserve system, Journal of globalization and development, 1(2), Article 13

Keynes JM (1930) A treatise on money, in the collected writings of John Maynard Keynes, volume VI, royal economic society. Macmillan, London, p 1971

Keynes JM (1943) Proposals for an international clearing union, British government publication, Cmd.6437, London (April). Reprinted in J. Keith Horsefield ed. (1969), The international monetary fund 1945-1965, volume III: documents, pp.19-36

Knack S, Rahman A (2007) Donor fragmentation and bureaucratic quality in aid recipients. J Dev Econ 83 (1):176-197

Knack S, Rogers HF, Eubank N (2011) Aid quality and donor rankings. World Dev 39(11):1907-1917

Kodama M (2012) Aid unpredictability and economic growth, world development. World Dev 40(2):266-272 
Levy Yeyati E (2008) The costs of reserves. Econ Lett 100(1):39-42

Lucas RE (1990) Why doesn't capital flow from rich to poor countries? Am Econ Rev 80(2):92-96

Machlup F (1966) Plans for reform of the international monetary system, in id. International monetary economics. Collected essays, Allen \& Unwin, London, ch.XIV, 282-366

Machlup F (1968) Remaking the international monetary system. The Rio agreement and beyond, J. Hopkins, Baltimore

Maynard G (1973) Special drawing rights and development aid. J Dev Stud 9(4):518-543

Micossi S, Saccomanni F (1981) The substitution account: the problem, the techniques and the politics. BNL Quarterly Review 137:171-189

Minoiu C, Reddy SG (2010) Development aid and economic growth: a positive long-run relation. The Quarterly Review of Economics and Finance 50(1):27-39

Morrissey O (2004) Conditionality and aid effectiveness re-evaluated. World Economy 27(2):153-171

Obstfeld M (2011) The SDR as an international reserve asset: what future? mimeo. University of California, Berkeley

Obstfeld M, Rogoff K (1995) The mirage of fixed exchange rate. J Econ Perspect 9(4):73-96

Obstfeld M, Shambaugh JC, Taylor AM (2010) Financial stability, the Trilemma, and international reserves. American Economic Journal: Macroeconomics 2(2):57-94

Ocampo JA (2010a) Building an SDR-based global reserve currency, journal of globalization and development, 1(2), Article 14

Ocampo JA (2010b) Special drawing rights and the reform of the global reserve system. In: Sundaram JK (ed) Reforming the international financial system for development. Columbia University Press, New York

Olivier G (2011) From colonialism to partnership in africa-europe relations? The International Spectator 46(1):53-67

Ouattara B, Strobl E (2008) Aid, policy and growth: does aid modality matter? Rev World Econ 144 (2):347-365

Padoa Schioppa T (2010) The ghost of Bancor: the economic crisis and global monetary disorder, Louvain-la-Neuve, 25 February

Pittaluga G, Seghezza E (2012) Euro vs. dollar: an improbable threat, open economies review, in this issue

Polak JJ (1979) Thoughts on an international monetary fund based fully on SDR, pamphlet series, $n^{\circ} 28$, international monetary fund

Prasad ES, Rogoff K, Wei S-J, Kose AM (2007) Financial globalization, growth and volatility in developing countries, NBER chapters, in Harrison, Ann (ed.) Globalization and poverty, national bureau of economic research, University of Chicago Press

Presbitero AF, Zazzaro A (2011) IMF lending programs in the wake of the global crisis: political influences and crisis prevention, mimeo, Università Politecnica delle Marche

Raddatz C (2007) Are external shocks responsible for the instability of output in low-income countries? J Dev Econ 84(1):155-187

Rajan RG, Subramanian A (2008) Aid and growth: what does the cross-country evidence really show? Rev Econ Stat 90(4):643-665

Robe MA, Pallage S (2001) Foreign aid and the business cycle. Rev Int Econ 9(4):641-672

Rodrik D (2006) The social cost of foreign exchange reserves. Int Econ J 20(3):253-266

Selaya P, Thiele R (2011) The impact of aid on bureaucratic quality: does the mode of delivery matter?, Journal of international development, forthcoming

Stiglitz JE (2003) Dealing with debt: how to reform the global financial system. Harvard Relations Council International Review 25(1):54-59

Stiglitz JE, Greenwald B (2010) Towards a new global reserve system, Journal of globalization and development, 1(2), Article 10

Triffin R (1960) Gold and the dollar crisis. Yale University Press, New Haven

Veillette C (2011) The future of U.S. aid reform: rhetoric, reality, and recommendations, center for global development, September

Williamson J (2009) Understanding special drawing rights, Policy brief, $n^{\circ} 09-11$, Peterson institute for international economics

Williamson J (2012) Rules for correcting external imbalances, Open economies review, in this issue

World Bank (2011) Multipolarity: the new global economy, global development horizons 2011, Washington DC

Zhou X (2009) Reform of the international monetary system, essay posted on the website of the people's bank of China, 9 April 